\title{
O DIÁlOGO IMAGEM-PALAVRA NA ARTE DO SÉCULO XX \\ as colagens cubistas de Pablo Picasso e sua relasăo intertextual com os caligramas de Guillaume Apollinaire
}

\author{
Maria do Carmo de Freitas Veneroso \\ UFMG
}

\begin{abstract}
RES U M O
Este estudo pretende discutir a relação entre palavra e imagem, aproximando artes plásticas e literatura, abordando o diálogo e as relações intertextuais no processo escritural nas artes no início do século XX. Serão focalizadas as relações entre imagem e texto no trabalho pioneiro de Pablo Picasso com suas colagens cubistas. Será estabelecida uma aproximação entre estas colagens e os poemas e caligramas de Guillaume Apollinaire, buscando-se mostrar pontos comuns entre os experimentos poéticos e gráficos do poeta e os papiers collés de Picasso.
\end{abstract}

\section{PALAVRAS - CHAVE}

Relações palavra/imagem, cubismo, colagem, caligrama

\section{A IMAGEM / ESCRITA}

Do passado caligráfico que me vejo obrigado a lhes supor, as palavras conservam sua derivação do desenho e seu estado de coisa desenhada: de modo que devo lê-las superpostas a si próprias; são palavras desenhando palavras [...]

Michel Foucault

Inúmeras são as relações entre texto e imagem, entre o universo da palavra escrita e o das artes visuais. Entretanto, por muito tempo (do século XV ao século XX), vigorou, na sociedade ocidental, um princípio que afirmava a separação entre signos lingüísticos e elementos plásticos. Esse princípio estabelece "a separação entre representação plástica (que implica a semelhança) e referência lingüística (que a exclui). Faz-se ver pela semelhança, fala-se através da diferença. De modo que os dois sistemas não podem se cruzar ou fundir". ${ }^{1}$ Desse modo, mesmo quando esse encontro se dava, ele era regido por alguma forma de subordinação, de hierarquia entre imagem e texto, indo da forma ao discurso ou do discurso à forma: a legenda, o título, a ilustração, a crítica de arte e todo discurso que gira em torno da pintura.

${ }^{1}$ FOUCAULT. Isto não é um cachimbo, p. 39. 
No século XX, as palavras (a letra, o texto) irrompem no espaço do quadro, integradas ao discurso plástico, passando o texto a interferir no interior mesmo da imagem, funcionando também como imagem. Paul Klee, entre outros, seria um dos artistas a abolir a soberania do princípio que estabelece a distinção entre representação plástica e referência lingüística:

ao colocar em destaque, num espaço incerto, reversível, flutuante (ao mesmo tempo tela e folha, toalha e volume, quadriculado do caderno e cadastro da terra, história e mapa), a justaposição das figuras e a sintaxe dos signos. Barcos, casas, gente, são ao mesmo tempo formas reconhecíveis e elementos de escrita. ${ }^{2}$

Também na poesia, encontra-se, na literatura ocidental e especificamente em "Un coup de dés", de Stéphane Mallarmé, uma tomada de consciência da visualidade dos signos lingüísticos e do espaço da página como elemento constitutivo do poema.

Esse diálogo que a arte do século XX estabelece com a escrita, ao mesmo tempo em que a escrita dialoga com a visualidade, reata, de certa maneira, antigos vínculos existentes entre a palavra e a imagem, entre o traço do desenho e o traço da escrita, revelando que a escrita não é apenas um meio de transcrição da fala, mas uma realidade dupla, dotada de uma parte visual. É nesse lugar limítrofe, nessa margem em que a escrita e as artes plásticas confluem, que se encontra um espaço privilegiado para se pensar as relações entre imagem e palavra. Trata-se, portanto, de um olhar a partir das bordas, dos momentos de cruzamento em que uma arte apreende, com a outra, recursos e formas de estruturação, momentos em que a imagem busca a letra e a letra busca a imagem. Esse cruzamento entre a arte e a escrita se dá, portanto, no século XX, através da apropriação de elementos textuais pela produção plástica e também por meio da apropriação de elementos plásticos pela produção textual.

\section{Uma idéia é um ponto de partida e nada mals... (Pablo Picasso)}

A aparição da palavra dentro do espaço do quadro, de uma maneira mais sistemática e integrada ao discurso plástico, pode ser notada a partir da produção dos pintores cubistas, na década de 1910. Porém, o que ocorre na arte no início do século XX é o resultado de mudanças que vão acontecer durante o século XIX. As idéias de progresso e de modernidade vão substituir o culto da natureza e a fascinação pela paisagem, presentes na produção pictórica do século XIX. As cidades com seus signos, marcas e grafismos dos anúncios de rua tomam o lugar das paisagens impressionistas.

A pintura vai, cada vez mais, se afastando da representação naturalista, a partir da segunda metade do século XIX. Com a popularização da fotografia, a pintura ganha autonomia. Através da apropriação de fragmentos da realidade urbana, como textos tipográficos, jornais, partituras musicais, embalagens, bilhetes de metrô, os pintores cubistas introduzem a palavra em suas colagens. A seguir, esses artistas começam a pintar as palavras sobre a tela, porém mantendo suas características tipográficas. Através da manipulação da palavra dentro de suas possibilidades lingüísticas, surgem os

${ }^{2}$ FOUCAULT. Isto não é um cachimbo, p. 40. 
trocadilhos e os jogos de associação. Outra característica da palavra pintada é sua autonomia gráfica, ou tipográfica: o artista evita toda interferência plástica personalizada, com a intenção de reproduzir a letra com o rigor de um pintor figurativo.

Os pintores cubistas trabalham a visualidade da letra, restituindo a ela sua característica de "coisa desenhada" e, ao mesmo tempo, fragmentando e desconstruindo seu significado ao inseri-la dentro de uma composição. Também os poetas, como Guillaume Apollinaire, vão explorar a visualidade da página. Esse poeta, com seus Calligrammes, explora os recursos formais do cubismo, fracionando a realidade através do uso de planos superpostos e simultâneos.

A partir das colagens cubistas de Picasso e dos caligramas de Apollinaire, surge uma nova visualidade da letra e da página, que tem início com o cubismo e irá se estender por todo o século XX, no trabalho de diferentes artistas e poetas.

\section{Cubismo e bRicolagem}

Como se sabe, o Cubismo vai surgir, basicamente, a partir de duas fontes: a influência de Cézanne sobre Georges Braque e o contato de Picasso com a escultura africana. Os pontos comuns entre essas duas fontes são o sentido de construção formal, como uma reação à linguagem invertebrada do impressionismo, bem como a preocupação formal que supera a intenção imitativa, dando seqüência ao processo de negação da representatividade já presente nos trabalhos dos pós-impressionistas. O Cubismo pode ser estudado a partir do tratamento que dá a um dos problemas centrais da arte pictórica desde o Renascimento: a relação do objeto com o espaço no qual ele é visto e a representação dessa relação dimensional em uma superfície plana. O Cubismo incorporou, pela primeira vez na arte ocidental, o princípio de que uma obra de arte, tanto na sua concepção quanto na sua aparência, tanto em sua essência quanto em sua substância, não precisa se restringir à aparência fenomenológica do objeto ao qual ela se refere. Os cubistas dão ênfase à construção estática, explorando o uso de eixos horizontais e verticais nas suas composições. Em sua fase áurea (1907-1914), o cubismo apresentou uma fase inicial, mais analítica, seguida por outra, mais sintética, em que os planos ganham independência. A fase seguinte é a fase hermética, onde ocorre a total planificação das formas: apesar de as figuras e objetos se tornarem quase imperceptíveis, eles estão lá, e com algum esforço podemos distinguilos. Assim, o cubismo nunca foi um estilo completamente abstrato, pois sempre guardou uma referência ao objeto representado, ainda que ela fosse vaga.

Em torno de 1911/12, começam a aparecer as primeiras letras desenhadas nos quadros cubistas: Braque inova, começando por colar um recorte de jornal em um de seus quadros. A partir daí, passa a enriquecer o quadro com elementos materiais tomados do mundo concreto, como fragmentos de jornais, papéis pintados, estopa, prego, cartões de visita, areia, envelopes. Também Juan Gris cola um pedaço de espelho na tela, ao invés de tentar imitar uma superfície de espelho. Entre 1912 e 1914, os quadros de Picasso e Braque tornam-se cada vez mais herméticos, tornando difícil distinguir alusões a figuras humanas ou objetos, como guitarras, cachimbos, cordas de violão, em meio às letras e algarismos desenhados, e papéis colados imitando mármore ou madeira. Isso tem sido interpretado como uma necessidade do artista de renovar o contato com a realidade. No entanto, as 
letras e papéis colados, longe de representarem alguma coisa, tinham a função de conferir textura ou de atuar como elementos plásticos em interação com os outros elementos do quadro. $\mathrm{O}$ aparecimento de letras pintadas na tela não significa uma volta à cópia do real, mas indica que a pintura deixou de ser um meio de representação dos objetos para se tornar uma realidade gráfica, visual.

Esses "textos visuais", criados por Picasso, mostram que o artista se apropria de letras, fragmentos de texto de jornal, partituras musicais, tirando-os do seu contexto e dando a eles outro significado: são textos-escrituras, sem o objetivo de comunicar uma mensagem, mas existindo como uma realidade em si mesma. A letra volta então a ser desenho, contribuindo para eliminar os limites entre o texto e a pintura.

Braque foi o primeiro a introduzir tipos comerciais nas suas pinturas: a palavra "BAL" e o número "10,40" em A Portuguesa (Fig.1) são as primeiras indicações do seu desejo de contrastar a simples presença de coisas ordinárias com os aspectos conceituais da figura principal. De modo análogo, em Ma Jolie (Fig.2), Picasso introduz letras comerciais,intensificando assim as distorções do cubismo analítico. Nessa obra, não existe distinção entre as formas sólidas (braços, joelhos, cotovelo, violão, mesa) e o espaço ao redor, pois massa e vazio se fundem e a localização precisa de objetos discretos em uma espécie de profundidade ilusória dá lugar a uma estrutura volátil de planos desmembrados, cujas posições espaciais são ambíguas. Às vezes, um objeto dá a impressão de estar ao mesmo tempo na frente e atrás de outro; luz e sombra criam uma fantástica geometria de superfícies, uma geometria que implica relações em uma profundidade ilusória, ao mesmo tempo em que insiste no achatamento da superfície. As palavras "Ma Jolie", escritas em grandes letras de imprensa, remetem não só ao título da pintura, mas também a uma canção popular na época em que o quadro foi pintado.

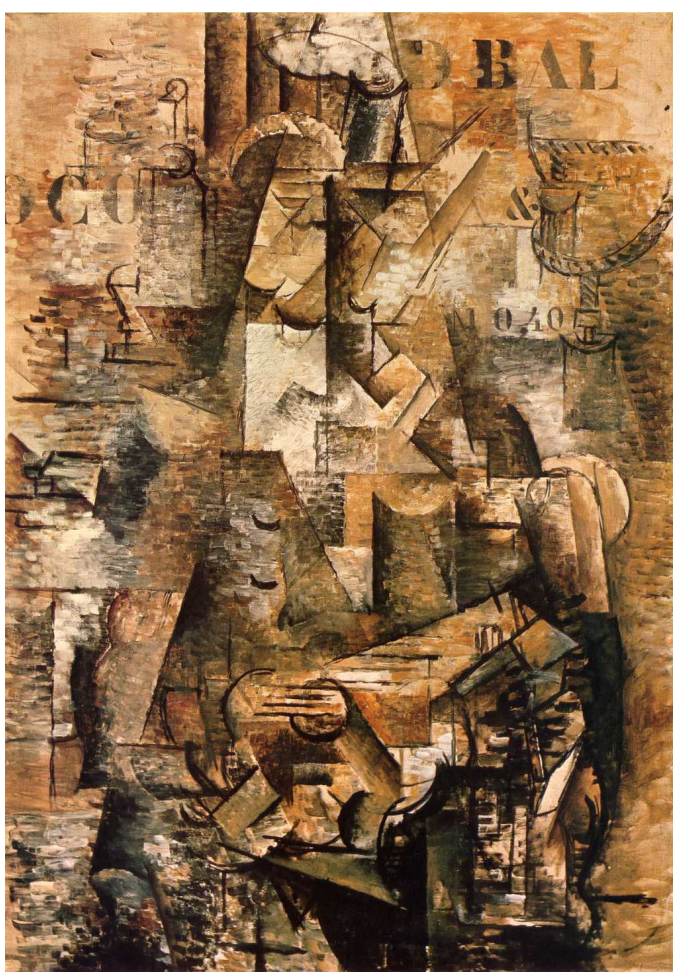

Fig. 1: Georges Braque (1882-1963), La Portuguèse, 1911. Óleo sobre tela, 116 x $81 \mathrm{~cm}$. Basiléia, Suíça: Kunstmuseum. Cf. Prancha 3, p. 378. 


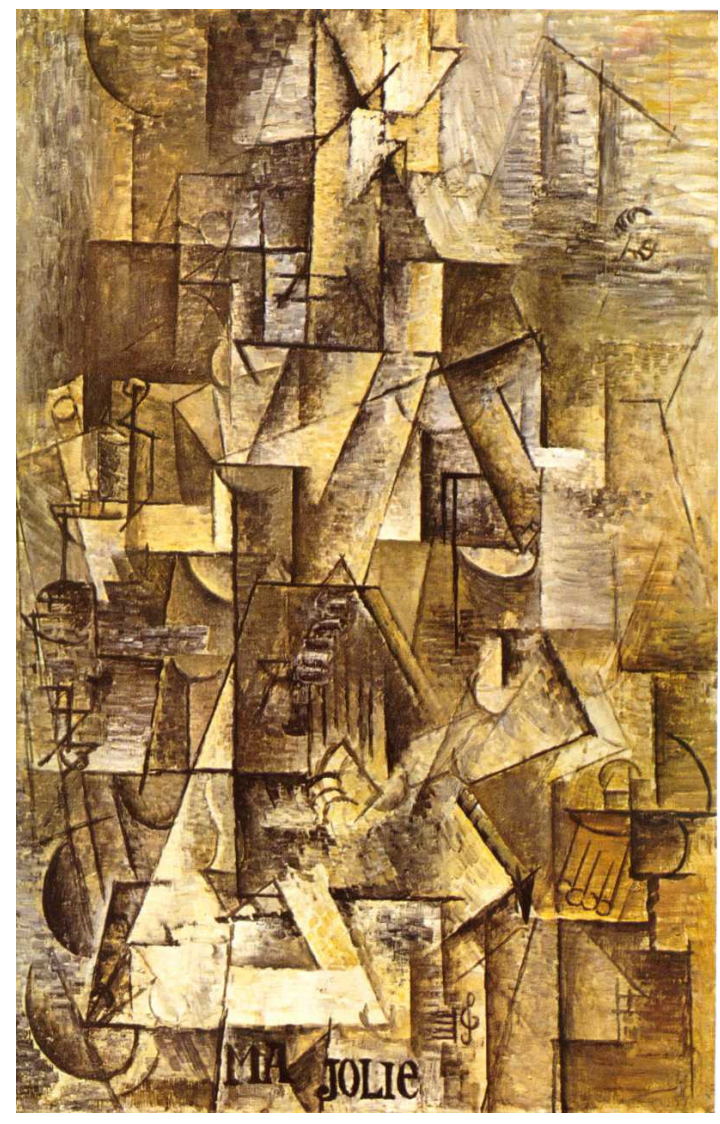

Fig. 2: Pablo Picasso(1881-1973), Ma Jolie, 1911-12. Óleo sobre tela, 100 x 65,4 cm. Nova York: The Museum of Modern Art.

Cf. Prancha 4, p. 379.

É importante aqui lembrar os experimentos gráficos que floresceram no século XIX e que deixaram sua marca não só nas artes visuais, mas também na literatura. Vários artistas atuantes entre 1880 e 1920 tiveram uma ligação profissional com as artes gráficas, produzindo cartazes e desenhos de publicidade; entre eles, Henri de Toulouse-Lautrec, Pierre Bonnard e Aleksandr Rodchenko, parceiro do poeta Vladimir Maiakovski em vários projetos publicitários durante a década de 20. A letra é, então, o próprio desenho, como vemos em "Un coup de dés”, de Mallarmé.

O cartaz ganhou grande importância na França entre o final do século XVIII e o final do século XIX. As técnicas de impressão tiveram, nessa época, um aperfeiçoamento extraordinário não só em relação à letra - a invenção do caractere Didot levou à proliferação de novos tipos - mas também em relação à reprodução da imagem. $\mathrm{O}$ surgimento da litografia, em 1796, simplificou consideravelmente os procedimentos da gravura, possibilitando a impressão em cores, que antes não era possível. Outro fato que levou a linguagem do cartaz a se desenvolver muito, nessa época, foi o surgimento da concorrência, provocado pelo desenvolvimento industrial.

Provavelmente, os experimentos gráficos do século XIX afetaram também Picasso que, atraído por seu vigor visual e por suas qualidades plásticas, passou a incorporá-los em seus trabalhos. Dentro do espaço cubista, ele usa recursos tipográficos como elementos integrantes da composição. Com isso, ele restituiu às letras sua "plenitude ativa de escritura": elas não estão ali para comunicar uma mensagem, pois têm um sentido de construção formal e valor plástico. Tudo isso, é claro, aliado ao espírito de pesquisa de Picasso, que mostra uma atitude não-convencional ao utilizar, em seus trabalhos, 
materiais pobres e sem o status "artístico". O impacto dessa atitude foi tão grande, que este se tornou um procedimento usual na arte do século XX, surgindo de novo em movimentos como o dadaísmo e a pop art.

Por volta de 1913, Picasso criou várias colagens utilizando jornais, todas com um mesmo caráter fragmentário. Essas colagens são como um "mosaico de citações" (Kristeva), em que Picasso incorpora elementos de escrita, criando novos sentidos. Em uma colagem do período, Garrafa sobre a mesa (Fig.3), o jornal aparece de uma maneira

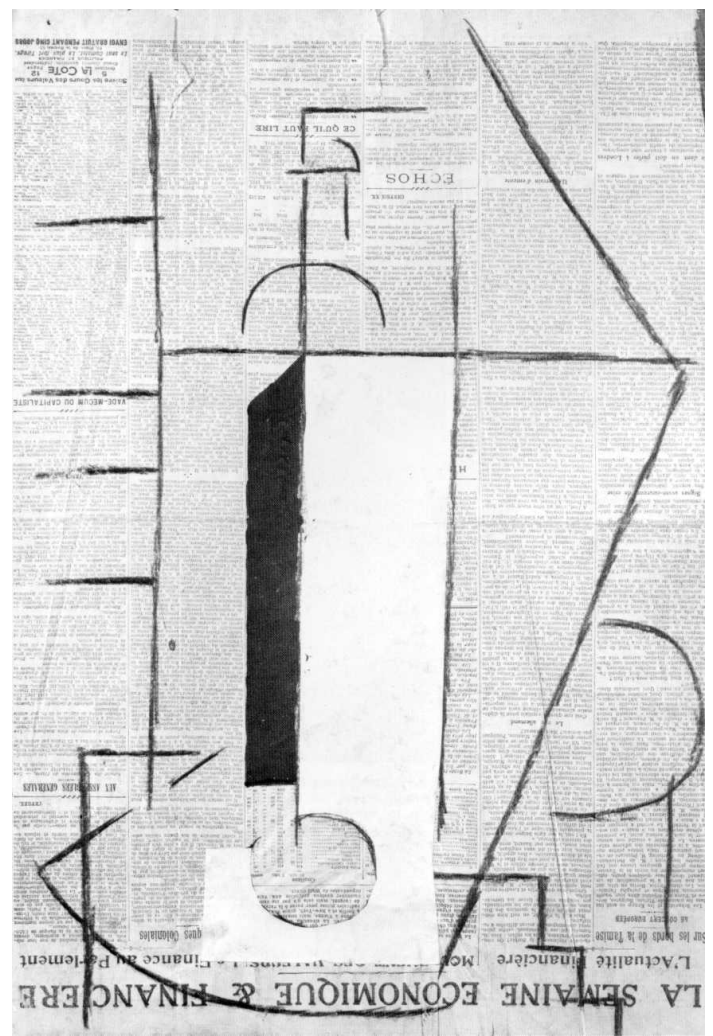

pouco legível. Praticamente todo o fundo é coberto pela textura do jornal, tornandose apenas uma forma retangular em branco, na área central da colagem, um pouco deslocada para baixo. O jornal foi colocado de cabeça para baixo, provavelmente com o objetivo de deixar claro que ele não estava ali para ser lido no sentido convencional, mas visualmente, com o menor número possível de elementos que distraíssem o espectador. O texto do jornal, em colunas, segue o mesmo padrão vertical-horizontal da grade cubista, e essas direções foram enfatizadas por Picasso, que traçou linhas pretas com carvão, sobre o jornal.

Fig. 3: Pablo Picasso, Bouteille sur la table, 1912-13. Papel colado e carvão sobre jornal, 62 x 44 cm. Paris: Musée Picasso.

Apesar da grande ênfase dada por Picasso aos aspectos visuais dos jornais usados em suas colagens, existem estudos que apontam para outra abordagem do uso do jornal por Picasso. David Cottington, num artigo intitulado "What the Papers Say: Politics and Ideology in Picasso's Collages of 1912", propõe uma leitura menos formalista para as colagens de Picasso. O autor cita Robert Rosenblum, ${ }^{3}$ cuja análise dessa fase de Picasso leva em consideração o tema contido nos fragmentos do material colado, confrontando seu significado verbal e visual. Para Rosenblum, esses trabalhos "estabeleceram, com uma vivacidade surpreendente, a conexão do Cubismo com a nova imagética do mundo moderno". ${ }^{4}$ David Cottington aponta, ainda, para o aparecimento de estudos sobre o Cubismo que

\footnotetext{
${ }^{3}$ Rosenblum é também citado por Rosalind Krauss no seu estudo Au nom de Picasso, no qual ela aborda, entre outras obras do artista, seus papiers collés. Cf. KRAUSS. L'originalité de l'avant garde et autres mythes modernistes, p. 187.

${ }^{4}$ ROSENBLUM. Picasso and the Typography of Cubism. In: GOLDING; PENROSE (Org.). Picasso, 1881-1973. Apud COTTINGTON. What the Papers Say: Politics and Ideology in Picasso's Collages of 1912, p. 350.
} 
exploram aspectos contextuais. Patricia Leighten, por exemplo, chama a atenção para a relevância dos eventos políticos e das ideologias para a prática artística de Picasso, indicando seu envolvimento no anarquismo de Barcelona na última década do século XIX e seu compromisso com o antimilitarismo. Dos cinqüenta e dois papiers collés de 1912-13 que contêm textos de jornais, pelo menos a metade tem a ver com a Guerra dos Bálcãs, acontecida naquela época, e com o estado político e econômico da Europa, sendo que a maioria dos trabalhos foi produzida no outono e inverno de 1912, quando Picasso inicia sua experimentação com essa técnica. Parece, além do mais, que esses recortes foram cuidadosamente selecionados, cortados e posicionados por Picasso, levando em consideração seu tema específico. Isso aponta, portanto, para a preocupação de Picasso com o ambiente político e social da Europa, mostrando que o tema contido nos seus papiers collés extrapolava seu próprio meio social.

As colagens de Picasso lembram os caligramas de Apollinaire, artista que, em seus experimentos gráficos, teve uma sensibilidade próxima à de Picasso. Ao mesmo tempo em que este experimentava o uso de letras e materiais diversos, estranhos à pintura, Apollinaire fazia experiências com o texto visual. Em "L'esprit nouveau et les poètes", publicado em 1918 no Mercure de France, Apollinaire observa que a poesia "deve ser como a página do jornal, da qual saltam simultaneamente aos olhos as coisas mais díspares". Apollinaire conheceu Picasso em 1905 e era um ardente defensor dos cubistas, sobre os quais publicou um livro em 1913. Segundo Herschel B. Chipp, em Teorias da arte moderna, ${ }^{5}$ este livro de Apollinaire sofreu várias revisões, nas quais o cubismo ganhava cada vez mais destaque: seu título original, Méditations esthétiques, acabou se tornando o subtítulo de Les peintres cubistes.

O termo cubismo, a princípio aplicado à pintura, seria aplicado também a um tipo de poesia "em que a realidade era também fracionada e expressa através de planos superpostos e simultâneos". ${ }^{6}$ Foi Apollinaire quem, de certa maneira, promoveu essa reunião de poesia e pintura sob uma mesma designação. Seu método de composição tinha certas características notáveis, como, por exemplo, a ausência de pontuação. Apollinaire afirmava que "no que diz respeito à pontuação, eu a suprimi apenas porque ela me pareceu inútil e ela o é realmente; o próprio ritmo e o corte dos versos, aí está a verdadeira pontuação, e não há nenhuma necessidade de outra". ${ }^{7}$ Apollinaire adota outros procedimentos que mostram que ele se orienta em direção a uma nova poesia quando, por exemplo, além de suprimir toda a pontuação, desarticula o verso regular, suprime a rima, compondo poemas que seguem disposições inéditas.

\section{As RELAÇões espaço/temPo No Cubismo e SEUS DESDOBRAMENTOS}

Dentro do contexto da passagem da cultura tipográfica para a eletrônica, podemos analisar o problema da simultaneidade no Cubismo e em Apollinaire. Octavio Paz, em Os Filhos do Barro, ao relacionar o cubismo na poesia e na pintura, afirma que essa relação não foi literária nem verbal, mas sim conceitual: mais que uma linguagem, os poetas tiraram

\footnotetext{
${ }^{5}$ CHIPP. Cubismo, p. 197.

${ }^{6}$ TELES. Vanguarda européia e modernismo brasileiro. p.114.

${ }^{7}$ SARRAZIN. Guillaume Apollinaire, p. 11-12.
} 
da experiência cubista uma estética. Paz considera uma das idéias centrais do cubismo a apresentação simultânea das diversas partes de um objeto - as anteriores e as posteriores, as visíveis e as escondidas - e as relações entre elas. O cubismo concebia o quadro como uma superfície onde, regidos por forças de atração e repulsão, se desdobram os elementos distintos externos e internos que compõem um objeto. O quadro cubista se converteu, assim, em um "sistema de relações plásticas". ${ }^{8}$

Paz também analisa a questão do simultaneísmo na poesia de Apollinaire, que não seria um simultaneismo ao pé da letra. ${ }^{9}$ Segundo Paz, a influência do pintor Robert Delaunay e do escritor Blaise Cendrars sobre Apollinaire foi fundamental para que o poeta pudesse colocar em termos poéticos a questão do simultaneísmo. Através da supressão dos nexos sintáticos - na poesia, um ato de conseqüências semelhantes à abolição da perspectiva para a pintura - e da justaposição, conseguiu criar uma sensação de simultaneidade. Como afirma Paz, "o presente de 'Zone', 'Le Musicien de Saint-Merry', 'Cortège' e outros poemas, recebe a afluência de todos os tempos, imobiliza-se e adquire a fixidez do espaço, enquanto o espaço flui, bifurca-se, volta a reunir-se consigo mesmo e perde-se. O espaço adquire as propriedades do tempo". ${ }^{10}$

Podemos ver o efeito de simultaneísmo em poemas como "Les Fenêtres" (1912), onde parece acontecer uma união de tempo/espaço. Esse efeito é conseguido, entre muitos outros meios, através da enumeração, nos últimos versos, de nomes de lugares sem ordem de distância. Sabe-se que esse poema foi escrito para o pintor em 1912 no atelier de Sonia e Robert Delaunay e publicado no catálogo da exposição realizada por ele na Galeria Der Sturm na Alemanha em 1913. O catálogo apresentava também reproduções da série de pinturas intituladas Fenêtres (Fig. 4) e Disques Circulaires, realizadas por Delaunay no mesmo ano em que o poema foi escrito. ${ }^{11}$

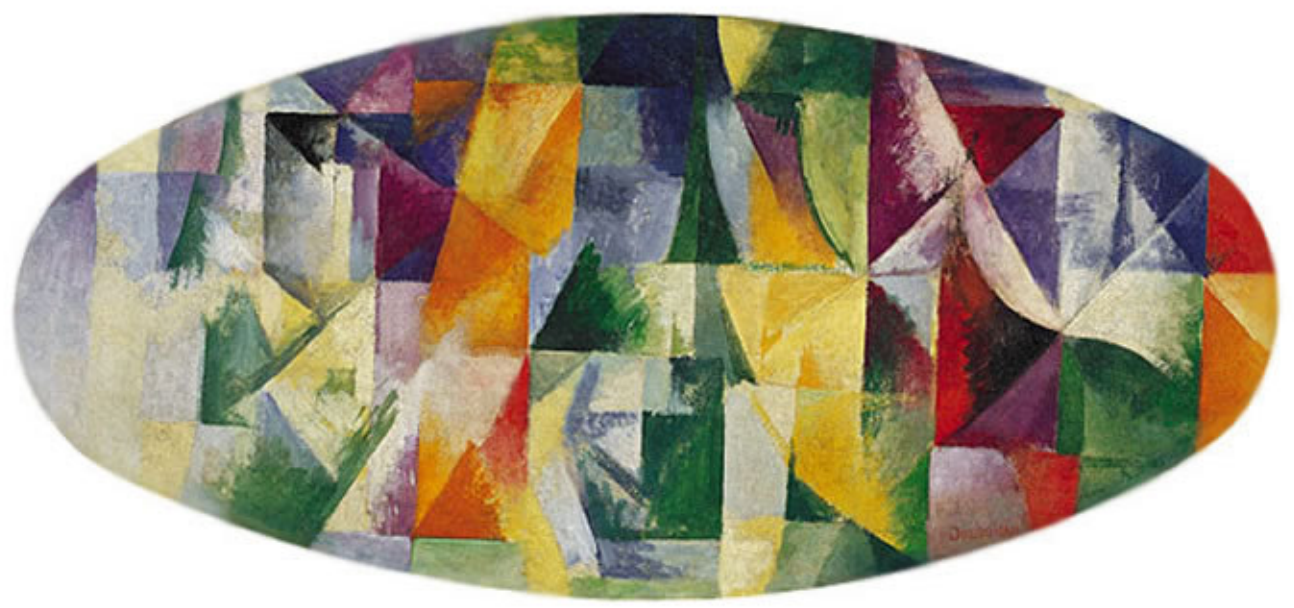

Fig. 4: Robert Delaunay (1885-1941), Fenêtres ouvertes simultanément: 1 1're partie, $3^{\text {er }}$ motif, 1912. Óleo sobre tela, 57 x 123 cm. Milão, Itália: Coleção Mattioli. Cf. Prancha 5, p. 378.

${ }^{8}$ PAZ. Os filhos do barro, p.153.

${ }^{9} \mathrm{PAZ}$. Os filhos do barro, p.157.

${ }^{10} \mathrm{PAZ}$. Os filhos do barro. p. 158.

${ }^{11} \mathrm{Cf}$. www.ac-orleans-tours.fr. 
A abertura do poema faz referências inegáveis a essas pinturas, que são retomadas no final:

Lês Fenêtres

Du rouge au vert tout le jaune se meurt

Quand chantent les aras dans les forêts natales

Abatis de pihis

Il y a un poème à faire sur l'oiseau qui n'a qu'une aile

Nous l'enverron em message téléphonique

Traumatisme géant

$[\ldots]$

Oû le train blanc de neige et de feux nocturnes fuit l'hiver

O Paris

Du rouge au vert tout le jaune se meurt

Paris Vancouver Hyères Maintenon New-York et les Antilles

La fenêtre s'ouvre comme une orange

Le beau fruit de la lumière

O poema é fragmentado, e percebe-se nele um processo de colagem de frases que ora se sucedem, ora se justapõem, remetendo a janelas que deixam ver várias cenas que se desdobram. Ao se confrontar o poema com as pinturas, percebe-se certas semelhanças entre ambos, como as cores, o tema comum e o efeito de simultaneidade e de justaposição. Pode-se dizer que o poema é um equivalente poético da pintura - ambos decompõem o mundo para melhor recriá-lo.

Também em Lettre-Océan (Fig. 5), poema em duas páginas, o efeito de simultaneísmo é conseguido, mas desta vez através da organização do poema em eixos que prolongam a visão para um horizonte longínquo; tudo se ordena em torno de um centro, do qual partem ondas simultâneas.

\section{LETTRE-OCEAAN}

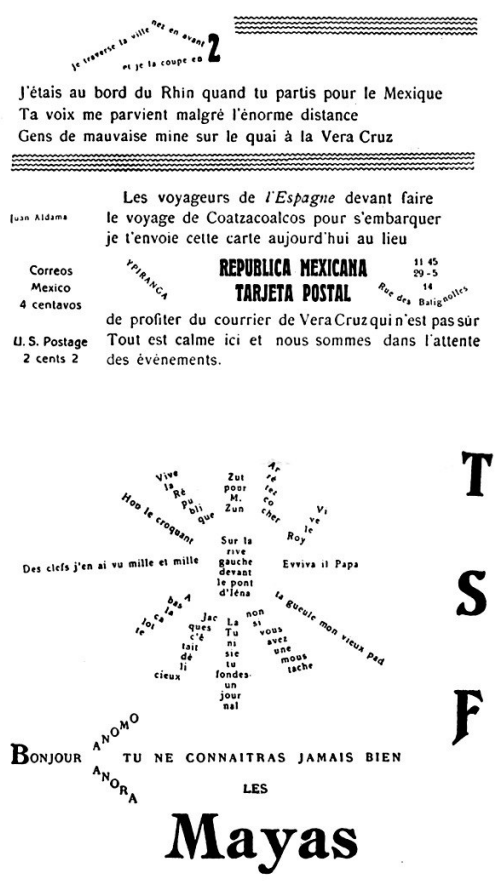

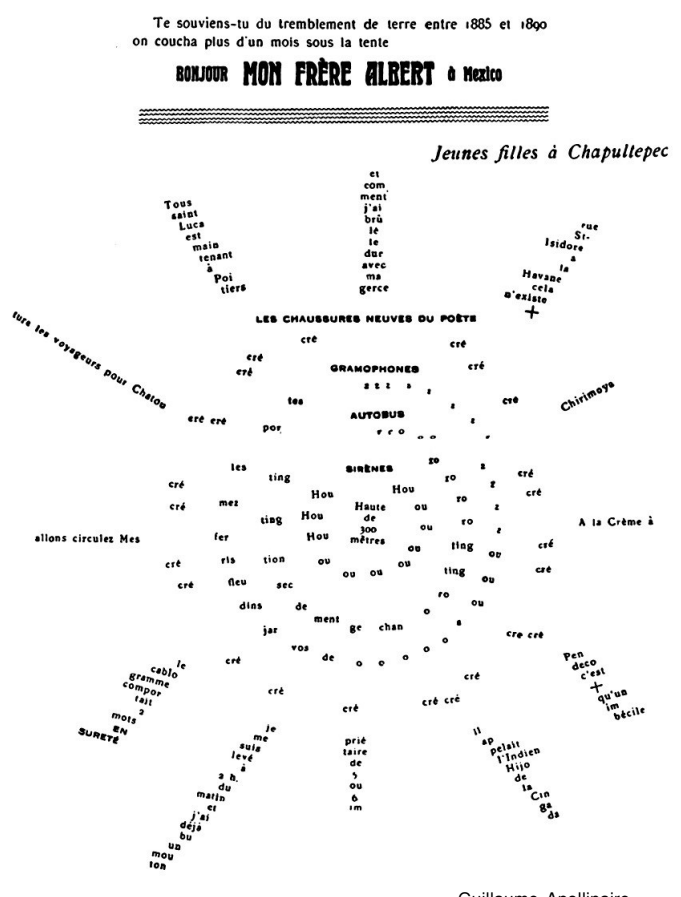

Guillaume Apollinaire

Fig. 5: Guillaume Apollinaire(1880-1918), Lettre-Océan, 1914. Impressão tipográfica sobre papel. 
Esse poema tem como tema a Torre Eiffel e seu uso como transmissor de um novo sistema de serviços telegráficos sem fio (representado pelas letras T S F). A imagem central de Lettre-Océan mostra a irradiação das mensagens no momento em que estão sendo transmitidas. O poema foi publicado no número de 15 de junho de 1914 de Soirées de Paris. ${ }^{12}$ Ele combina elementos escritos e desenhados, apresentando-se sobretudo como um conjunto vigorosamente composto e organizado, tanto do ponto de vista tipográfico quanto plástico, pois não há uma oposição entre os aspectos textual, caligramático e plástico desse poema. Ele foi considerado por alguns críticos da época, como G. Arbouin, como um "poema ideográfico". O autor considerou-o revolucionário e afirmou: "Revolução: porque é preciso que nossa inteligência se habitue a uma compreensão sintéticoideográfica, e não analítico-discursiva". ${ }^{13}$

A obra se aproxima de outros trabalhos contemporâneos, como os dos Futuristas ou de Robert Delaunay, que tal qual Lettre-Océan também ecoam as preocupações cosmopolitas da época, na França, na Itália e em outros países, por parte dos pintores e escritores. Essas preocupações incluíam o desejo de estar simultaneamente em vários lugares, e a idéia do "simultaneísmo" foi traduzida de diferentes maneiras, tanto verbal quanto visualmente. Lettre-Océan,

Fig. 6: Filippo Tommaso Marinetti (1876-

1944), Parole in libertà, 1919. Impressão tipográfica sobre papel.
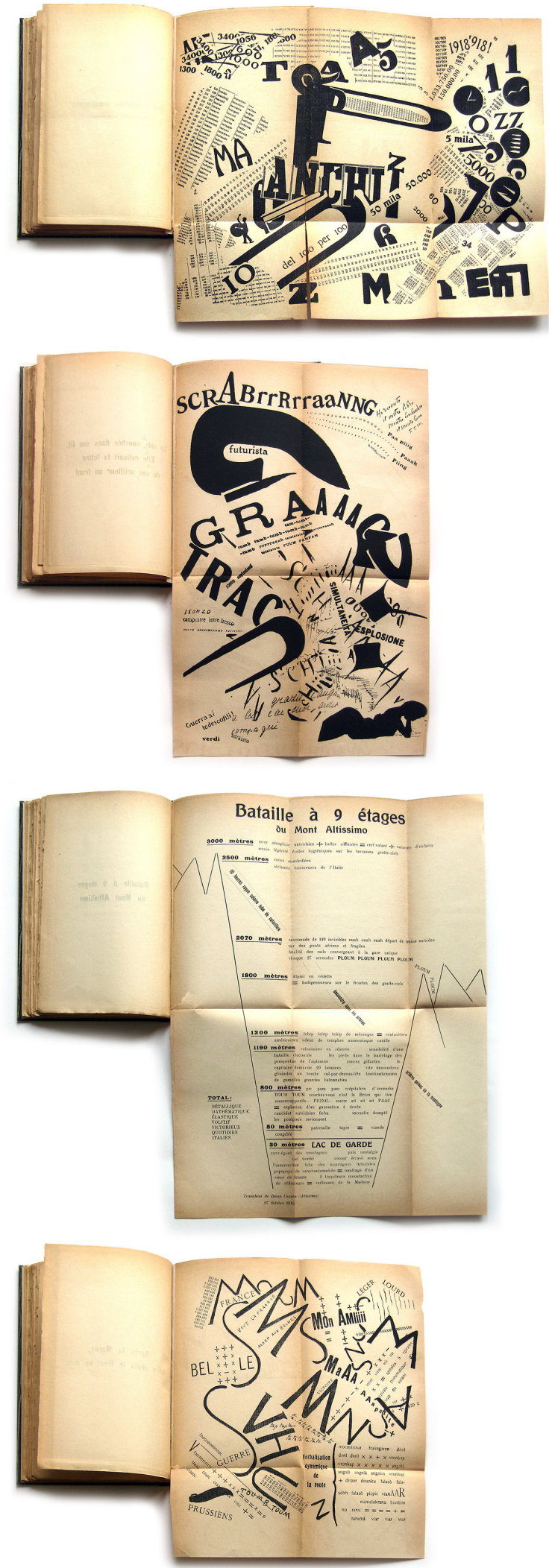

${ }^{12}$ Cf. DELBREIL; DININMAN; WINDSOR. Lettre-Océan.

${ }^{13}$ Arbouin apud DELBREIL; DININMAN; WINDSOR. Lettre-Océan. 
como outras obras da época, celebra os novos meios de comunicação, como o telefone e o telégrafo sem fio, e também a evolução mecânica, que levou à fabricação de navios e aviões que permitiram uma vitória sobre o espaço-tempo. Experiências simultaneístas foram feitas neste poema e mais tarde também no uso da tipografia pelos Futuristas, principalmente nas Parole in libertá que Filippe Tommaso Marinetti começou a compor em 1914 (Fig. 6). Aproximadamente sete semanas depois da publicação de poema de Lettre-Océan, o artista Carlo Carrà publicou a colagem Dipinto Parolibero (Festa Patriottica), conhecida mais tarde como "Manifestazione Intervencionista" (Fig. 7), cuja composição remete ao poema. O texto cita também fragmentos das Parole in libertà de Marinetti.

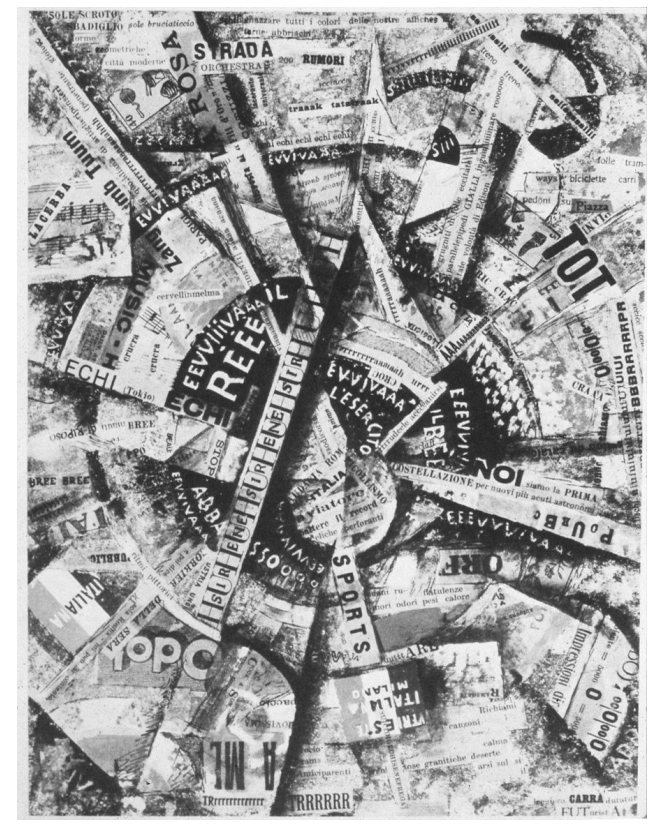

Fig. 7: Carlo Carrà (1881-1966), Manifestazione Intervencionista, 1914. Colagem sobre cartão, 38,5 x $30 \mathrm{~cm}$. Milão, Itália: Coleção Mattioli.

O procedimento de colagem evocado no estudo tipográfico de Lettre-Océan, ${ }^{14}$ ainda que não tenha aparecido na sua impressão final, também aproxima esse caligrama de certas telas de Picasso, Braque e Juan Gris. Um cartão postal parece "colado" ao caligrama, assim como muitos selos, remetendo à maneira como os pintores cubistas colavam sobre suas telas e lhes integravam fragmentos de artigos de jornal ou de cartões postais e cartas. Mas se procurarmos por uma aproximação entre Lettre-Océan e a estética cubista, é sobretudo na sua composição espacial, na existência de formas propriamente cubistas e linhas geométricas fortemente estruturadas que iremos encontrá-la. Porém, é muito maior a proximidade de Lettre-Océan com as obras dos Futuristas e com as teorias expostas nos seus vários manifestos, e principalmente com as pinturas de Robert Delaunay, como a sua série de Tours Eiffel (Fig. 8), iniciada em 1909. Nessa série de pinturas, além de o tema ser o mesmo do poema de Apollinaire, também a forma circular é enfatizada como no poema. A idéia de simultaneidade é transmitida pelas duas obras, mostrando que a sensibilidade da época apontava para uma ênfase nesse aspecto, trazido à tona

\footnotetext{
${ }^{14}$ Esse, assim como os outros caligramas de Apollinaire, eram primeiramente projetados a mão, para mais tarde serem impressos em tipografia, resultando portanto em duas versões de cada um deles.
} 
pelos novos meios de comunicação e também pelos meios de transporte que diminuíram as distâncias. A Fig. 8 é uma homenagem ao aeronauta Blériot.

Fig. 8: Robert Delaunay, Hommage à Blériot, 1914. Óleo/tela, 761/2 x 501/2 in.

Basiléia, Suíça: Kunstmuseum.

Cf. Prancha 6, p. 379.

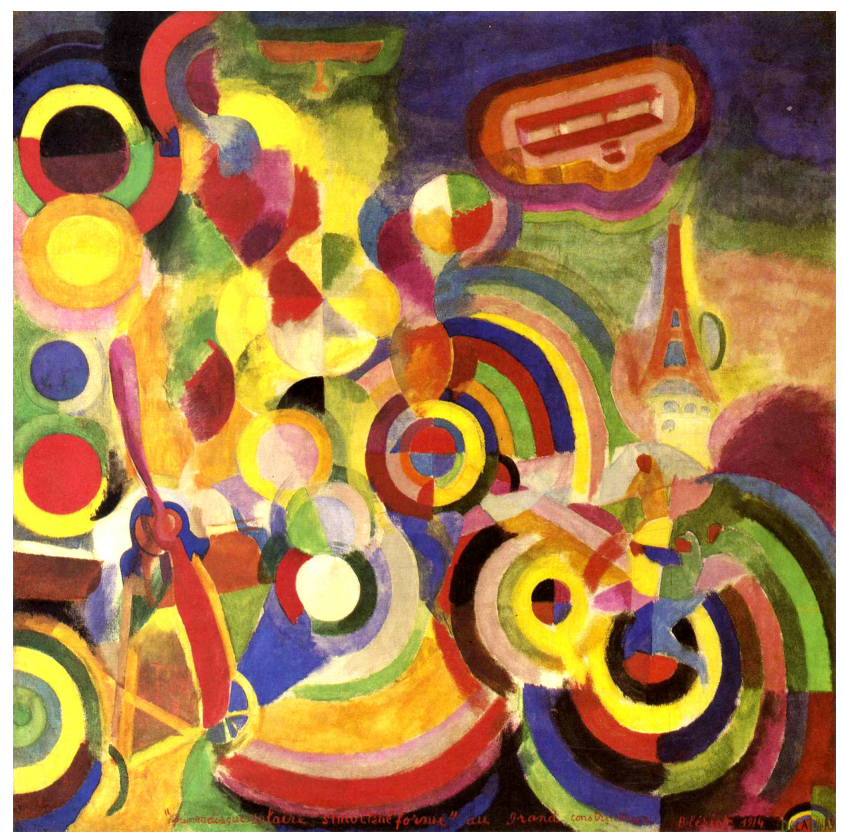

\section{A ESCRITA CALIGRAMÁTICA}

O caligrama (...) se serve dessa propriedade das letras, que consiste em valer ao mesmo tempo como elementos lineares que se pode dispor no espaço e como sinais que se deve desenrolar segundo o encadeamento único da substância sonora. Sinal, a letra permite fixar as palavras; linha, ela permite figurar a coisa. Assim, o caligrama pretende apagar ludicamente as mais velhas oposições de nossa civilização alfabética: mostrar e nomear; figurar e dizer; reproduzir e articular; imitar e significar; olhar e ler.

Michel Foucault

Os Calligrammes, poemas iniciados por volta de 1913 por Apollinaire, "representam", na leitura de Chip, "uma tentativa de construir poemas e até mesmo dispô-los na página impressa de acordo com os recursos formais do cubismo". ${ }^{15}$ Outros, como Hubert Sarrazin, associam esses poemas à tradição dos carmina figurata, que remete à antiguidade: na maioria desses "poemas figurados", a aparência gráfica ou a forma do poema evoca o objeto descrito ou evocado pelo texto verbal. Assim, o poema "As Asas de Eros" de Símias de Rhodes (fl. 300 a. C.) tem a forma de duas asas. Poemas desse tipo foram também criados na era Cristã e tiveram um renascimento nos séculos XVII e XVIII. Etimologicamente, calligramme tem sua origem no grego kalos, belo, bonito, e grama, letra, escritura. Mas enquanto calligramme denota tradicionalmente "poema figurado" no sentido descrito acima, ${ }^{16}$ a relação entre texto e imagem nos caligramas de Apollinaire geralmente não é tautológica.

\footnotetext{
${ }^{15}$ CHIPP. Cubismo, p. 197.

${ }^{16}$ ROBERT. Le nouveau Petit Robert, p. 289.
} 
No caligrama "O bandolim, a violeta e o bambu", por exemplo, as tres formas representam os objetos denominados no título. (A versão manuscrita reproduzida na Fig. 9 serviu de modelo para a versão tipográfica a ser impressa, da mesma forma que a Lettre-Océan; mas a edições modernas tem a tendência de publicar os manuscritos originais dos caligramas de Apollinaire, que foram redescobertas.) Os textos verbais que constituem as formas têm uma relação mais complexa, metafórica aos objetos representados:

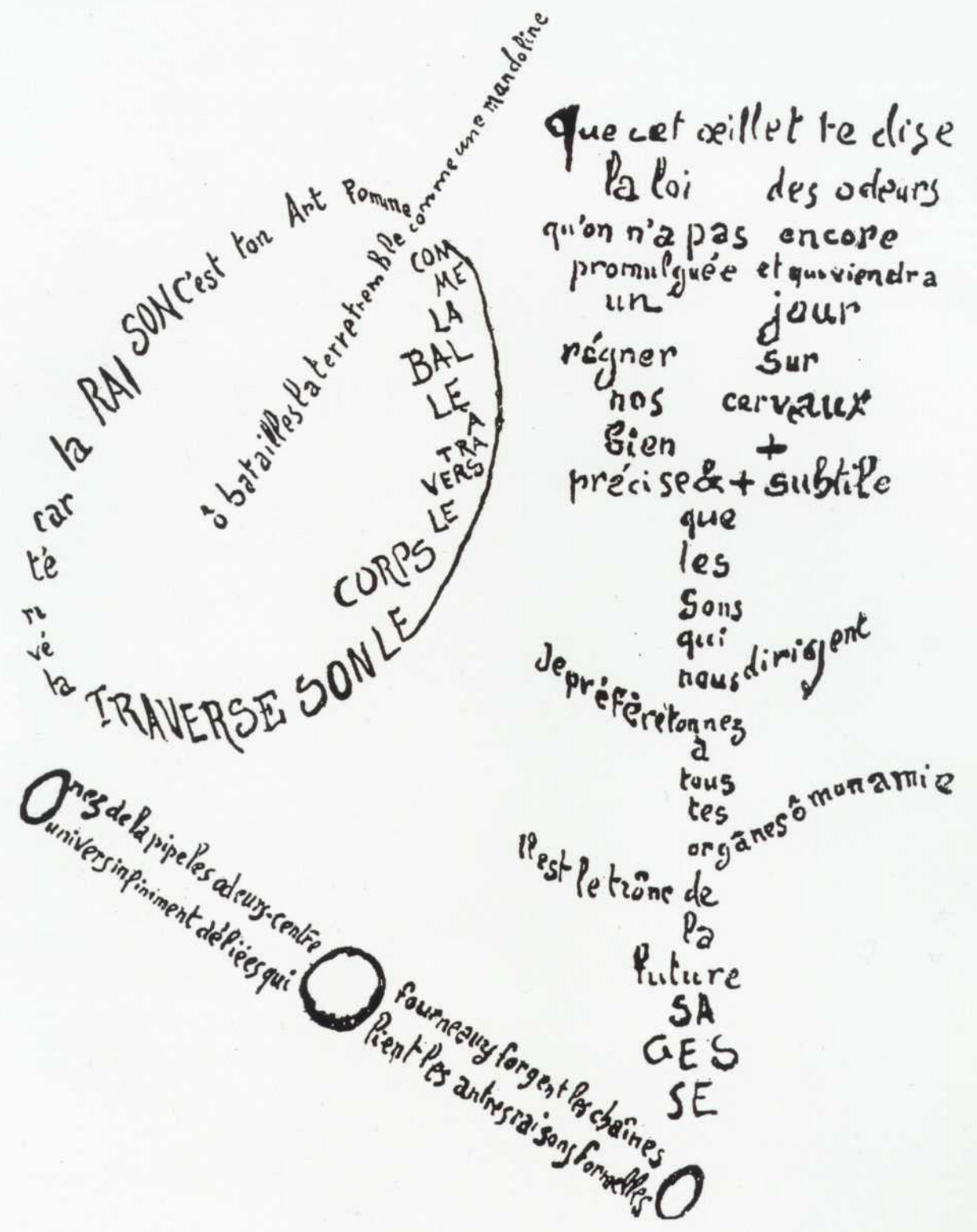

Fig. 9: Guillaume Apollinaire, La Mandoline l'CEillet et le Bambou. Caligrama.

[La mandoline / o bandolim]

Comme la balle atravers le corps le son traverse la verité car la raison cést ton Art femme ô batailles la terre tremble comme une mandoline
Como a bala atravez do corpo o som atravessa a verdade porque a razão é sua Arte mulher ô batalhas a terra treme como um bandolim 


\section{[Lœíllet / a violeta]}

Que cet œillet te dise

la loi des odeurs

qu'on n'a pas encore

promulguée et qui viendra

un jour régner sur nos cerveaux

bien + précise $\&+$ subtile

que les sons qui nous dirigent

Je préfère ton nez à tous tes organes

ô mon amie

il est le trône de la future SAGESSE
Que essa violeta te diga

a lei dos cheiros

que ainda não foi divulgada

e que um dia virá

reinar sobre nossos cérebros

bem + precisa \& + sutil

do que os sons que nos dirigem

Eu prefiro seu nariz a todos os seus orgãos

ô minha amada

ele é o trono da SABEDORIA futura

[Le bambou / o bambu]

O nez de la pipe les odeurs-centres univers infiniment déliées qui

O nariz do cachimbo os odores-centrais Universo infinitamente finas
O fourneau y forgent les chaînes liant les autres raisons formelles

O forja lá formam as correntes ligando as outras razões formais

\section{Observações finais}

Apollinaire interessou-se, desde a juventude, pelos caracteres cuneiformes e chineses, além de ter demonstrado sensibilidade pelos velhos "beaux livres" da Idade Média e da Renascença. Isso o preparou para perceber logo a importância da introdução de letras e palavras pelos cubistas em seus quadros, interpretando esse fato no contexto da revolução cultural que começava a se esboçar.

Apollinaire mostra uma visão lúcida, ao declarar: "quanto aos Calligrammes, eles são uma idealização da poesia de verso-livre e uma precisão tipográfica em uma época em que a tipografia termina brilhantemente sua carreira, à aurora dos novos meios de reprodução que são o cinema e o fonógrafo". ${ }^{17}$ Dessa forma, o poeta deixa claro que estava consciente da dinâmica dos meios de reprodução. Assim como os artistas plásticos, ele, um poeta interessado pelos aspectos visuais da poesia, lança mão dos recursos tipográficos em seus poemas, num momento em que a tipografia já começa a ser suplantada por outros meios de reprodução.

Picasso e Apollinaire legaram uma contribuição importante para a criação de uma nova visualidade no século XX, em que a letra volta a ser valorizada pelas suas qualidades visuais, através das relações que esses artistas estabelecem entre imagem e texto, e na concretização de um novo espaço plástico. Assistimos hoje a inúmeras possibilidades de articulação espacial que apontam para algo novo, ainda não totalmente claro. A importante revolução que teve lugar com o cubismo, e que levou à destruição do espaço plástico do Renascimento e ao surgimento de um novo espaço, pode estar chegando ao fim, suplantada pelos novos questionamentos trazidos pela cibercultura e pela virtualização.

${ }^{17}$ APOLLINAIRE apud BUTOR. Préface. In: APOLLINAIRE. Calligrammes, p.7. 


\section{A B S TR A C T}

This text aims at studying the dialogue and intertextual relationships which operate in the process of écriture within the arts in the early 20th century. Relationships between image and text are discussed in the pioneering work of Pablo Picasso's Cubist collages and Guillaume Apollinaire's poems and calligrams.

\section{KEYWORDS}

Word/image relations, Cubism, collage, calligram

\section{REFERÊNCIAS}

APOLLINAIRE, Guillaume. Calligrammes. Préface: Michel Butor. Paris: Gallimard, 1966. CHIPP, Herschel B. Cubismo: A forma como expressão. Introdução. In: CHIPP, Herschel B. (Org.). Teorias da arte moderna. (1968.) Trad.Waltencir Dutra et al. São Paulo: Martins Fontes, 1988, p. 197.

COTTINGTON, David. What the Papers Say: Politics and Ideology in Picasso's Collages of 1912. Art Journal, vol. 47, n. 4, p. 350-359, Winter 1988.

DELBREIL, Daniel; DININMAN, Françoise; WINDSOR, Alan. Lettre-Océan. $<$ www.wiu.edu/Apollinaire/Archives_Que_Vlo-Ve/1-21-22_1-38_Lettre-Ocean> Consulta em 14/12/2007.

FOUCAULT, Michel. Isto nno é um cachimbo. (1973.) Trad. Jorge Coli. Rio de Janeiro: Paz e Terra, 1989.

KRAUSS. Rosalind. L'originalité de l'avant garde et autres mythes modernistes. (1985.) Trad. Jean-Pierre Criqui. Paris: Macula, 1993.

PAZ, Octavio. Os filhos do barro. (1974.) Trad. Olga Savary. Rio de Janeiro: Nova Fronteira, 1984.

ROBERT, Paul. Le Nouveau Petit Robert. Paris: Dictionnaires Le Robert, 1993.

SARRAZIN, Hubert. Guillaume Apollinaire. Recife: Universidade de Recife, 1958.

TELES, Gilberto Mendonça. Vanguarda européia e modernismo brasileiro. Petrópolis: Vozes, 1986. <www.ac-orleans-tours.fr > Consulta em 14/12/2007. 